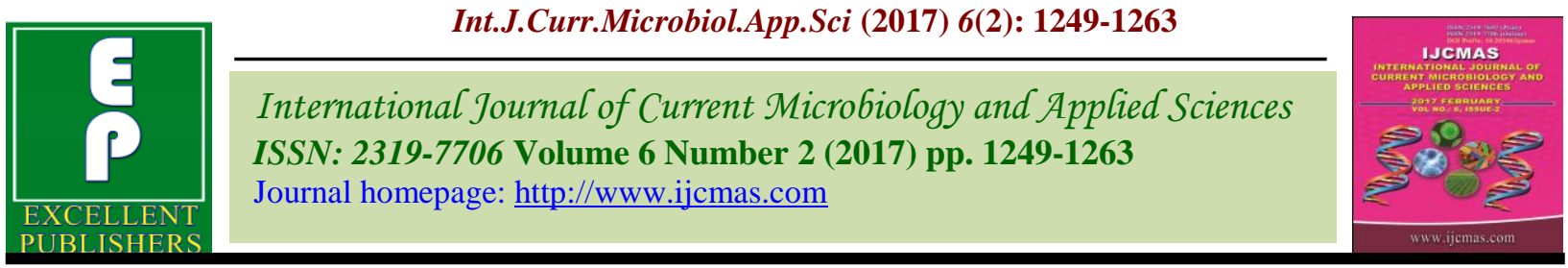

Original Research Article

http://dx.doi.org/10.20546/ijcmas.2017.602.141

\title{
Water Quality Monitoring of Yamuna River by Using GIS Based Water Quality Index in Delhi, India
}

\author{
Shikha Sharma ${ }^{1}$, Pawan Kumar Jha², Manju Rawat Ranjan', \\ Umesh Kumar Singh $^{3}$ and Tanu Jindal ${ }^{1}$
}
${ }^{1}$ Amity Institute of Environmental Sciences, Amity University, Uttar Pradesh 201303, India
${ }^{2}$ Centre of Environmental Studies, University of Allahabad, Uttar Pradesh 211002, India
${ }^{3}$ Integrated Science Education and Research Centre (ISERC), Visva-Bharati University, Santiniketan- 731235, India
*Corresponding author

\section{A B S T R A C T}

In climate change scenario the availability of fresh water for human use has become one of the key concerns and due to increasing pollution load from various anthropogenic sources and runoff from agricultural land had put a tremendous pressure on the available water resources in terms of its quality. Yamuna River is extremely polluted in the Delhi region

Keywords

River pollution,

Yamuna,

Nutrients,

WQI, GIS.

Article Info

Accepted:

22 January 2017

Available Online:

10 February 2017 and has been extensively studied for selected parameters. The water sample of Yamuna River was collected from 10 different locations of Delhi region starting from Wazirabad (Ram Ghat) to Okhla barrage in the month of June 2015 and December 2015. The samples collected were then analyzed for different physicochemical parameters including $\mathrm{pH}$, TDS (total dissolved solids), EC (electrical conductivity), DO (dissolved oxygen), BOD (biochemical oxygen demand) and nutrient concentrations such as nitrate, nitrite, ammonia, phosphate and silica to determine the seasonal variation. The concentration of dissolved nutrients (nitrate, nitrite, ammonia and phosphate) in the River water of Delhi was found relatively higher in comparison to the concentration which was found in an unpolluted river (Meybeck 1979, 1982) and this indicated that nutrient chemistry of river is highly influenced by the anthropogenic activities taking place in the river catchment area. Water quality indices (WQI) were introduced and calculated to reduce great amount of parameters into a simpler expression which enables easy interpretation of monitoring data.WQI was determined for three segments of Delhi (Upper, middle and down segment) and has found very high $(>100)$. In this study, Final representation of water quality index (WQI) has been done on the GIS map to show spatial variation of pollution level in the entire Delhi stretch.

\section{Introduction}

The surface water bodies are the most important sources of water for human activities and are unfortunately under severe environmental stress as a consequence of developmental activities. In the past decades, rapid increase of human activities has increased the transport of nutrients from land to sea, resulting in environmental deterioration and changes to biogeochemical processes (Seitzing et al., 2005; Halpern et al., 2008; Qu and Kroeze, 2010). The Conversion of land from forest to other land 
uses causes overland flow of storm runoff and suspended sediment and nutrient exports (Hopkinson and Vallino, 1995; Williams and Melack, 1997). The factors which control the loading rate of $\mathrm{N}, \mathrm{P}$ and $\mathrm{Si}$ into rivers are dissimilar. Due to landuse changes towards more agricultural and urban uses, the total amounts of $\mathrm{N}$ and $\mathrm{P}$ exported rise rapidly (Young et al., 1996).

Pollution of the environment can be estimated by the level of contamination in rivers, lakes and other reservoirs. There are sites of accumulation of polluting impurities which comes from human activity, due to dissolution, precipitation and adsorption (Abdel-Satar, 2010).

Horton in 1965 initially proposed an index method. Since then all the water supply agencies has been strongly recommended to use indices. WQI were introduced to generate a single value for the water quality of a source. In general, water quality indices incorporate data from multiple water quality parameters into a mathematical equation that defines the health of a water body with number. Numerous water quality indices have been formulated all over the world like National sanitation foundation - WQI (Brown et al., 1970), Oregon WQI (Cude, 2001), British Columbia WQI (BCMOELP, 1995), Canadian Council of Minister of the Environment -WQI (CCME, 2001) to assess the water quality.

The Yamuna river when passes through Delhi, it receives large volumes of domestic and industrial effluents during its course, especially between Wazirabad and Okhla (Paliwal et al., 2006). Heavy discharges of untreated domestic sewage and nonavailability of dilution, has degraded the quality of water in the Delhi stretch of the river (Goel et al., 2008). The Objective of this study is to assess the pollution status of river water quality by detecting nutrient concentrations and WQI which is then finally depicted using Geographical information system (GIS).

\section{Study area and methods}

The Yamuna River, $1376 \mathrm{~km}$ is the largest tributary of the Ganga River. The river originates from the Yamunotri glacier near Banderpunch peaks of lower Himalayas $\left(38^{\circ}\right.$ $59^{\prime} \mathrm{N}$ and $78^{\circ} 27^{\prime} \mathrm{E}$ ) in the mussorie range at an elevation of about 6387 meter above from mean sea level of Uttarkashi district (Uttarakhand) and flows through seven states - The total catchment basin area of the Yamuna river is $3,66,223 \mathrm{~km}^{2}$ (catchment area in various states i.e. $3,45,848 \mathrm{~km}^{2}$ and Yamuna river area i.e. $20,375 \mathrm{~km}^{2}$ ) which is $42.5 \%$ of Ganga basin and $10.7 \%$ of the total geographical landmass of the country (CPCB 2006).

This study covers the $22 \mathrm{~km}$ Delhi stretch of Yamuna which includes 10 different locations starting from Wazirabad to Okhla barrage. The water samples $(n=10)$ were collected in the acid washed polyethylene bottles from the Yamuna river in the pre-monsoon (June 2015) and post-monsoon (December 2015) season. Samples were collected in duplicates from the river at the depth of $15-20 \mathrm{~cm}$. On-site measurements included measurements of Total Dissolved Solids (TDS), Electrical Conductivity (EC), pH and Dissolved oxygen (DO) using multi parameter probe from Hanna (HI 9828). Samples were then transported in an ice box to the laboratory. In the laboratory, water samples were filtered through precombusted and preweighted 0.45 micron nylon filter paper and then analyzed for dissolved nitrate $\left(\mathrm{NO}_{3}{ }^{-}\right)$, nitrite $\left(\mathrm{NO}_{2}{ }^{-}\right)$, ammonia $\left(\mathrm{NH}_{3}\right)$, phosphate $\left(\mathrm{PO}_{4}{ }^{3-}\right)$, and silica $\left(\mathrm{SiO}_{2}\right)$ by using photometrically method given by APHA , 1998 using UV -VIS Spectrophotometer (Thermo Scientific). BOD was analyzed using Winkler's method by incubating samples for five days at $20^{\circ} \mathrm{C}$. 


\section{GIS integration}

For the better interpretation of the analyzed results, the concentrations of different parameters obtained at various locations were integrated with GIS. The study area is delineated from landsat 8OLI data dated 2016-05-21 path 146 row 40. The spatial database generated from analysis of samples was integrated with GIS for the preparation of spatial distribution map of water quality as WQI. The water quality parameters data has been converted into point data for interpolation to see the effective nature of changing water quality in the river Yamuna at different location.

The kriging interpolation method is applied to generate the thematic water quality variation map and water quality index to see the spatial distribution of water quality over river Yamuna. The main characteristic of interpolation method is to estimate the intermediate values from the true values. Therefore using the spatial analyst tool in GIS surface variation of water quality by using kriging method has been established than using IDW. It is the best linear unbiased estimator spatial distribution analysis; it is also recommended by environmental protection agency that kriging would be more accurate option for water quality studies (Gundogdu et al., 2007, Uyan et al., 2010). Kriging is an advance method of geospatial procedure for interpolation which generates an estimated surface from the distance and direction between sample points which reflects spatial correlation (Rawat et al., 2012). This method becomes appropriate where there is know there is a spatially correlated distance or directional prejudice in the data like with down flowing of the river makes it dirtier. Kriging method not only weights the distance between two points but also checks the direction and over all arrangements of the data. Especially kriging is used in those areas where the distribution of true values is not densely distributed. It is assumed that the spatial variation in the data is being modeled homogeneously across the surface (Isaaks and Srivastava, 1989).Using this integration, final map showing spatial distribution was prepared to easily identify the variation in concentrations of the different parameters in the Yamuna river water.

\section{Water quality index (WQI)}

Water quality index provides a single number to expresses overall water quality at a certain location and time, based on several water quality parameters. In this study, six parameters $(\mathrm{pH}$, TDS, DO, BOD, Nitrate, Ammonia) were chosen for the calculation of water quality index. WQI has been calculated by using the standards of drinking water quality as recommended by bureau of Indian standards (BIS) and Indian Council for Medical Research (ICMR). To study WQI Delhi Yamuna river is divided into three segments, Upper segment (Ram ghat, Wazirabad barrage and Majnu ka Tila), Middle segment (Nigam bodh ghat, ITO, I.P power plant and Nizamuddin bridge) and Down segment (Mayur vihar, Yamuna bank and Okhla barrage).

The weighted arithmetic index method has been used for the calculation of WQI of the river (Brown et. al.). Quality rating or sub index $(q n)$ was calculated using the following expression.

$q n=100[V n-V i o] /[S n-V i o]$

(Let there be $\boldsymbol{n}$ water quality parameters and quality rating or subindex (qn) corresponding to $\boldsymbol{n}^{\text {th }}$ parameter is a number reflecting the relative value of this parameter in the polluted water with respect to its standard permissible value.)

$\boldsymbol{q} \boldsymbol{n}=$ Quality rating for the $\boldsymbol{n}^{\text {th }}$ Water quality parameter 
$\boldsymbol{V} \boldsymbol{n}=$ Estimated value of the $\boldsymbol{n}^{\text {th }}$ parameter at a given sampling station.

$\boldsymbol{S}$ n $=$ Standard permissible value of the $\boldsymbol{n}^{\text {th }}$ parameter.

$\boldsymbol{V}_{i o}=$ Ideal value of $\boldsymbol{n}^{\text {th }}$ parameter in pure water. (i.e., 0 for all other parameters except the parameter $\mathrm{pH}$ and Dissolved oxygen (7.0 and $14.6 \mathrm{mg} / \mathrm{L}$ respectively)

Unit weight was calculated by a value inversely proportional to the recommended standard value $\boldsymbol{S n}$ of the corresponding parameter.

$W n=\mathrm{K} / S n$

$\boldsymbol{W n}=$ unit weight for the $\boldsymbol{n}^{\text {th }}$ parameters.

$\boldsymbol{S n}=$ Standard value for $\boldsymbol{n}^{\text {th }}$ parameters

$\mathbf{K}=$ Constant for proportionality.

The overall Water Quality Index was calculated by aggregating the quality rating with the unit weight linearly.

$\mathrm{WQI}=\Sigma q n W n / \Sigma W n$

\section{Results and Discussion}

The seasonal variation in physico-chemical and nutrient parameters of river water is shown in Figure 2a, $2 \mathrm{~b}$ and the results of water analysis with mean and standard deviation values of different parameters are summarized in Table 3.

The Yamuna River in Delhi receives discharge from the 22 drains from Wazirabad to Okhla. Due to poor condition of trunk sewers, shortage of sewage treatment capacity and lack of sanitation facilities in unsewered area, Delhi alone contributes around 3,296 MLD/day of sewage through drains falling in Yamuna Delhi segment water. This concentration of sewage generated is more than that of all the class 2 cities of India put together (Jain et al., 2007). The water quality is highly deteriorated along the 22-km Delhi stretch due to lack of minimum perennial fresh water flow in the river. The premonsoon concentration of nitrate, nitrite, ammonium, phosphate and silica in the water samples of Yamuna River varied as $0.29 \pm 0.31,0.09 \pm 0.12,7.74 \pm 3.00,1.90 \pm 1.79$ and $3.08 \pm 1.18(\mathrm{mg} / \mathrm{l})$. The post-monsoon concentration of nitrate, nitrite, ammonium, phosphate and silica varied as $1.66 \pm 0.89$, $0.19 \pm 0.21, \quad 5.31 \pm 3.47, \quad 0.95 \pm 0.51 \quad$ and $3.96 \pm 1.13(\mathrm{mg} / \mathrm{l})$. The concentration of nitrate, nitrite and phosphate were not found high in river water of Delhi region as it majorly depends on the agricultural runoff present in the river basin. Silica concentration was in the range of 0.53 to $5.4(\mathrm{mg} / \mathrm{l})$ in Yamuna river system. Silica concentration in river water mainly depends upon the weathering rate in catchment area along with silica uptake by biota in stream channel.

Figure $2 \mathrm{~b}$ shows the seasonal variation in $\mathrm{pH}$, TDS, EC, DO and BOD. $\mathrm{pH}$ of Yamuna river water was found alkaline in nature and varied from 7.02-8.4. All the aquatic organisms are affected by the change in $\mathrm{pH}$ as most of their metabolic activities are $\mathrm{pH}$ dependent (Wang et al., 2002). For the sustainable aquatic life the optimal range of $\mathrm{pH}$ is 6.5 to 8.2 (Murdock et al., 2001). Total dissolved solids (TDS) varied from 198 to 1017 (mg/l) and Electrical conductivity (EC) varied from 392-2034 $(\mu \mathrm{s} / \mathrm{cm})$ in both the premonsoon and post-monsoon season which indicates anthropogenic input mainly from domestic and industrial waste which also contributes to the high organic matter load in the Yamuna river sediments.

The concentration of dissolved oxygen in water body regulates the distribution of flora and fauna. DO value in the present study along Delhi stretch varied between 0.4 to 6.4 $\mathrm{mg} / \mathrm{l}$. The depletion of oxygen could be attributed to excessive, which disturbed the river ecosystem to a large extent. Seasonally, 
the average concentration of dissolved oxygen was found more during post- monsoon as $2.31 \pm 2.01(\mathrm{mg} / \mathrm{l})$ and less during premonsoon as $2.24 \pm 1.95(\mathrm{mg} / \mathrm{l})$.

DO was found highest at Wazirabad in Delhi due to low BOD. Bio-chemical oxygen demand assesses the organic load in a water body. Many researchers have recorded higher BOD values in polluted water. The BOD concentration ranged between $12 \mathrm{mg} / 1$ to 39 $\mathrm{mg} / 1$ indicating that the Delhi Yamuna river water is eutrophic. The minimum value of BOD was observed at Ram ghat (Wazirabad) and maximum value at Old ITO. Seasonally, BOD was found high during summer, being in conformity with the observation of Chatterjee (1992).

WQI of the present study was calculated using different physicochemical and nutrient parameters in two different seasons. The spatial variation of WQI for Delhi stretches integrated with GIS is shown in figure 3. The WQI for Yamuna river in Delhi was found more than 100 for all the three segments which indicates that the river water is highly polluted and is unsuitable for drinking (Table 4).WQI for Upper segment of Yamuna river was found lowest as 195.91 because of the less pollution load as the river enters the city and as we move downwards towards middle segment the WQI has been also increased and found maximum as 275.76 which indicates that this is the most polluted Part of the Delhi. The down segment WQI was found as 259.73 which is less then middle segment. The middle stretches showed the highest WQI in comparison to upper and lower because of more industrial and domestic sewage waste which leads to high organic loading in the mid Delhi regions.

In this research study, the primary focus was on eight water quality parameters $\mathrm{pH}$, TDS, EC, DO, BOD, Nitrate, Nitrite, Ammonia,
Phosphate and Silica. WQI was calculated to understand the suitability of surface water for human consumption (Atulegwu and Njoku, 2004). It was observed that the water quality falls in the poor range of WQI for different locations in Delhi from Wazirabad to Okhla barrage. The water quality at these locations was majorly impacted by the wastewater discharge generated from the NCT, entering the river through various drains. Kambalagere et al., 2007 reported high value of WQI in different seasons i.e., rainy season, winter season and summer season as 96, 101.7 and 106.3 respectively. The high value of WQI indicates the poor quality of water as also reported in other river studies (Chatterji and Raziuddin, 2002). WQI was found in the range of 160 to 300 for downstream Yamuna river water in the year 2002 and 2003 (Kumar et al. 2015). For Ganga River the WQI found in range of 15 to 1700 in 2007 and 2008 (Chauhan et al., 2010) which reflects its unsuitability for human use (Bahera et al., 2004). The WQI obtained in our study for three different segments of river were 195.91, 275.76 and 259.73 , which clearly shows that the status of the water body is eutrophic and is unfit for use. The WQI was found highest at middle Delhi stretch was may be due to more drains effluents, domestic sewage, agriculture run off, washing, bathing, cremation and dumping of human and animal dead bodies. It was also noted that $\mathrm{pH}$ was the only parameter which was meeting the standard for water quality in the stretch. $\mathrm{pH}$ of the river ranged between 7.02 to 8.4 which indicated that water is slightly alkaline in nature, Ambasht (1971), Petre (1975), Shardendu and Ambasht (1988), Swarnalatha and Narasingarao (1993) and Sinha (1995) have also made the similar observations in their studies of water bodies. The concentration of TDS in water body tends to be diluted by surface runoff and for most of the rivers there is an inverse correlation was found between discharge rate and TDS (Charkhabi and 
Sakizadeh, 2006). TDS and EC were found higher in summer which may be due to the fact of more solubility of ions at higher temperature. Annual average concentration of TDS was reported as $117.4 \mathrm{mg} / \mathrm{l}$ in Yamuna river of Delhi segment (Sharma et al., 2012) and in the year 1998-1999 it was reported as 512 to $1024 \mathrm{mg} / \mathrm{l}$ in summer and 448 to 768 $\mathrm{mg} / \mathrm{l}$ in winter for Delhi and downstream region. DO was reported in the range of 5.4 to $8.7 \mathrm{mg} / \mathrm{l}$ for the entire Yamuna stretch except the Okhla barrage $(0.5 \mathrm{mg} / \mathrm{l})$ in Delhi region (Rani et al., 2013). Our study has also showed the similar trend and varied from 0.4 to $6.4 \mathrm{mg} / \mathrm{l}$ for Delhi region. Dissolved oxygen for Delhi stretch was found below $4 \mathrm{mg} / \mathrm{l}$ for maximum locations which indicates that Delhi river water is highly eutrophicated. The DO concentration was found normal from its origin to Palla but beyond that as it enters wazirabad (Delhi) the DO levels starts declining drastically and at many points in Delhi downstream regions it was also found nil (Misra, 2010). Delhi contributes approximately 3,296 MLD/day of sewage carried by the drain that fall out directly in Yamuna river water of $22 \mathrm{~km}$ Delhi segment (Mandal et al., 2010). Due to such high organic loading the Annual average BOD in Delhi River water was reported as $21.8 \mathrm{mg} / \mathrm{l}$ for 2006-2007 year (Sharma et al., 2012) and $33.6 \mathrm{mg} / \mathrm{l}$ at Okhla barrage in Delhi for the year 2010 (Rani et al., 2013). Unpolluted natural waters have BOD of $5 \mathrm{mg} / \mathrm{l}$ or less (Schulze et al., 2001) and BOD for Delhi stretch was always found higher which is responsible for the depletion of oxygen from the Yamuna river water.

Nitrate and phosphate concentration was reported as 1.38 to $2.9 \mathrm{mg} / \mathrm{l}$ and 0.02 to 0.256 $\mathrm{mg} / \mathrm{l}$ in the year of 2010-2011 (Kaur and Singh, 2012) in Delhi region. High concentration of nitrate and phosphate in river water is derived from anthropogenic sources like untreated domestic sewage, agricultural watershed and storm water which contain nitrogenous compounds. Annual average concentration of nitrate in the shoreline zone of Yamuna river water for the year 20062007 was reported as $0.22 \mathrm{mg} / \mathrm{l}$ (Sharma et al., 2012). In our study the concentration of nitrate varied as 0.14 to $3.52 \mathrm{mg} / \mathrm{l}$ which is approximately similar to the concentration found in year 2006, 2007, 2010 and 2011 due to the agricultural activities that took place in the river catchment area. Phosphate concentration was found in the range of 0.03 $6.09 \mathrm{mg} / \mathrm{l}$ for Delhi region which is very high in comparison to the concentration reported in 2010-2011 year (Kaur and Singh, 2012). The increase in concentration can be due to the increased industrial activities and untreated waste disposal in the river water of Yamuna. For unpolluted river the Concentration of nitrate should be $0.10 \mathrm{mg} / \mathrm{l}$ or less and Phosphate concentration should be $0.01 \mathrm{mg} / \mathrm{l}$ or less (Meybeck, 1982). In our study area the concentration of nitrate and phosphate was found significantly high in both the seasons and was more than $0.1 \mathrm{mg} / \mathrm{l}$ and $0.01 \mathrm{mg} / \mathrm{l}$ for most of the location which indicated that the river water in Delhi stretch is highly contaminated with the high nutrient concentration and is leading to more eutrophic condition then in the year of 2010 and 2011. Highest concentration of nitrate was found at Wazirabad and Okhla barrage this may be attributed to livestock's or agricultural farms located around river area. The phosphate enters the surface water through different sources which include approximately $45 \%$ domestic, $45 \%$ agriculture and the rest comes from industrial and background sources (Morse et al., 1993).

The excessive loading of Ammonia in the Yamuna has also negatively influenced the quality of the river. Ammonia is readily available to marine life and other microorganisms in the form of nitrogen. The presence of ammonia and nitrogenous sources 
in large amount leads to eutrophication, algal bloom and anoxic conditions (Elmanama et al., 2006). Anil Kumar Misra, 2010 reported that the concentration of ammonia in the entire stretch of Yamuna River varies from 0 to $44 \mathrm{mg} / \mathrm{l}$ in the year 1999 to 2005 . In Delhi region often for most of locations the ammonia concentration has been found more than $0.4 \mathrm{mg} / \mathrm{l}$ in the Yamuna river water especially during summer (Misra, 2010). The annual average concentration of ammonia for the year 2006 and 2007 was reported as 0.07 $\mathrm{mg} / \mathrm{l}$ (Sharma et al., 2012). The concentration of ammonia in our study was found in the range of $0.1-12 \mathrm{mg} / \mathrm{l}$ which is more than double of the concentration detected in 2011 due to more discharge of domestic waste in river water. As the river passes through Delhi-NCR it becomes polluted through both point and non-point sources. The river receives both partially treated and untreated wastewater from the various wastewater drains. A huge amount of organic waste is added from the domestic sewage waste and from industries which leads to the escalation of BOD and depletion of DO. The WQI was found maximum in the middle segment of Delhi as D/S Nizamuddin in addition to wastewater via drains; the river also receives a major load from the Hindon river discharge which flows through U.P (Sharma et al., 2012). The river flows like an open sewer $\mathrm{d} / \mathrm{s}$ Wazirabad throughout the year and there is even no aquatic life in Delhi stretch. The major reason for the degradation of river water quality include addition of huge quantity of wastewater generated from the city and no fresh water flow in the river as also studied by various water quality monitoring studies (Paliwal et al., 2007; Sharma and Singh, 2009). The sewage treatment capacity of 512.4 MGD (2,321 MLD) is existed in the city but treatment was possible for only 348.04 MGD (1,546 MLD) (State of Environment Report for Delhi 2010).

Table.1 Drinking water standards and recommending agencies.

(All values except $\mathrm{pH}$ are in $\mathrm{mg} / \mathrm{L}$ )

\begin{tabular}{|l|l|l|}
\hline Parameters & Standards & Recommended agency \\
\hline $\mathrm{pH}$ & $6.5-8.5$ & ICMR/BIS \\
\hline TDS & 500 & ICMR/BIS \\
\hline DO & 5.00 & ICMR/BIS \\
\hline BOD & 5.00 & ICMR \\
\hline Nitrate $\left(\mathrm{NO}_{3}{ }^{-}\right)$ & 45 & ICMR/BIS \\
\hline Ammonia $\left(\mathrm{NH}_{4}{ }^{+}\right)$ & $<1.2$ & BIS \\
\hline
\end{tabular}

Table.2 Water Quality Index (WQI) and status of water quality (Chatterji and Raziuddin 2002)

\begin{tabular}{|l|l|}
\hline Water quality Index Level & Water quality status \\
\hline $0-25$ & Excellent water quality \\
\hline $26-50$ & Good water quality \\
\hline $51-75$ & Poor water quality \\
\hline $76-100$ & Very Poor water quality \\
\hline$>100$ & Unsuitable for drinking \\
\hline
\end{tabular}


Table.3 Pre-monsoon and Post-monsoon concentration of nutrients in the Yamuna River water

\begin{tabular}{|c|c|c|}
\hline Yamuna River Delhi & $\begin{array}{c}\text { Pre-Monsoon } \\
\text { (Mean } \pm \text { S.D })\end{array}$ & $\begin{array}{c}\text { Post-Monsoon } \\
\text { (Mean } \pm \text { S.D })\end{array}$ \\
\hline $\mathrm{pH}$ & $7.34 \pm 0.16$ & $7.57 \pm 0.33$ \\
\hline $\mathrm{TDS}(\mathrm{mg} / \mathrm{l})$ & $678.1 \pm 236.65$ & $380.8 \pm 109.51$ \\
\hline $\mathrm{EC}(\mu \mathrm{s} / \mathrm{cm})$ & $1359.3 \pm 476.95$ & $763.1 \pm 222.5$ \\
\hline $\mathrm{DO}(\mathrm{mg} / \mathrm{l})$ & $2.24 \pm 1.95$ & $2.31 \pm 2.01$ \\
\hline $\mathrm{BOD}(\mathrm{mg} / \mathrm{l})$ & $25.90 \pm 6.59$ & $24.90 \pm 8.44$ \\
\hline $\mathrm{NO}_{3}{ }^{-}(\mathrm{mg} / \mathrm{l})$ & $0.29 \pm 0.31$ & $1.66 \pm 0.89$ \\
\hline $\mathrm{NO}_{2}{ }^{-}(\mathrm{mg} / \mathrm{l})$ & $0.09 \pm 0.12$ & $0.19 \pm 0.21$ \\
\hline $\mathrm{NH}_{4}{ }^{+}(\mathrm{mg} / \mathrm{l})$ & $7.74 \pm 3.0$ & $5.31 \pm 3.47$ \\
\hline $\mathrm{PO}_{4}{ }^{-}(\mathrm{mg} / \mathrm{l})$ & $1.90 \pm 1.79$ & $0.95 \pm 0.51$ \\
\hline $\mathrm{SiO}_{2}(\mathrm{mg} / \mathrm{l})$ & $3.08 \pm 1.18$ & $3.96 \pm 1.13$ \\
\hline
\end{tabular}

Fig.1 Map of study area showing major sampling locations of Yamuna River in Delhi region

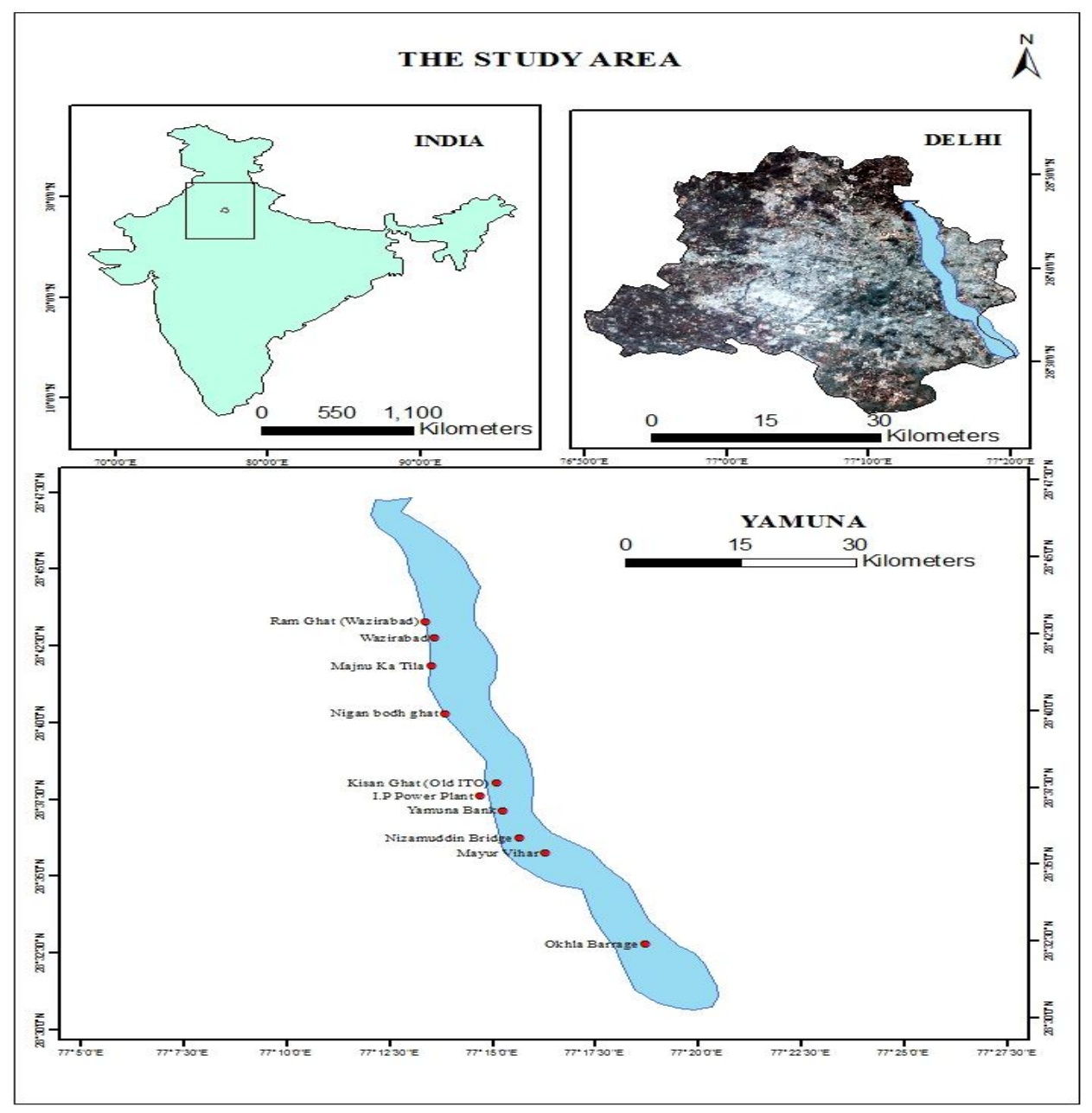


Fig.2a Seasonal variation of nutrients concentration at different locations in Delhi region Yamuna water: nitrate, nitrite, ammonia, phosphate and silica $(\mathrm{mg} / \mathrm{l})$
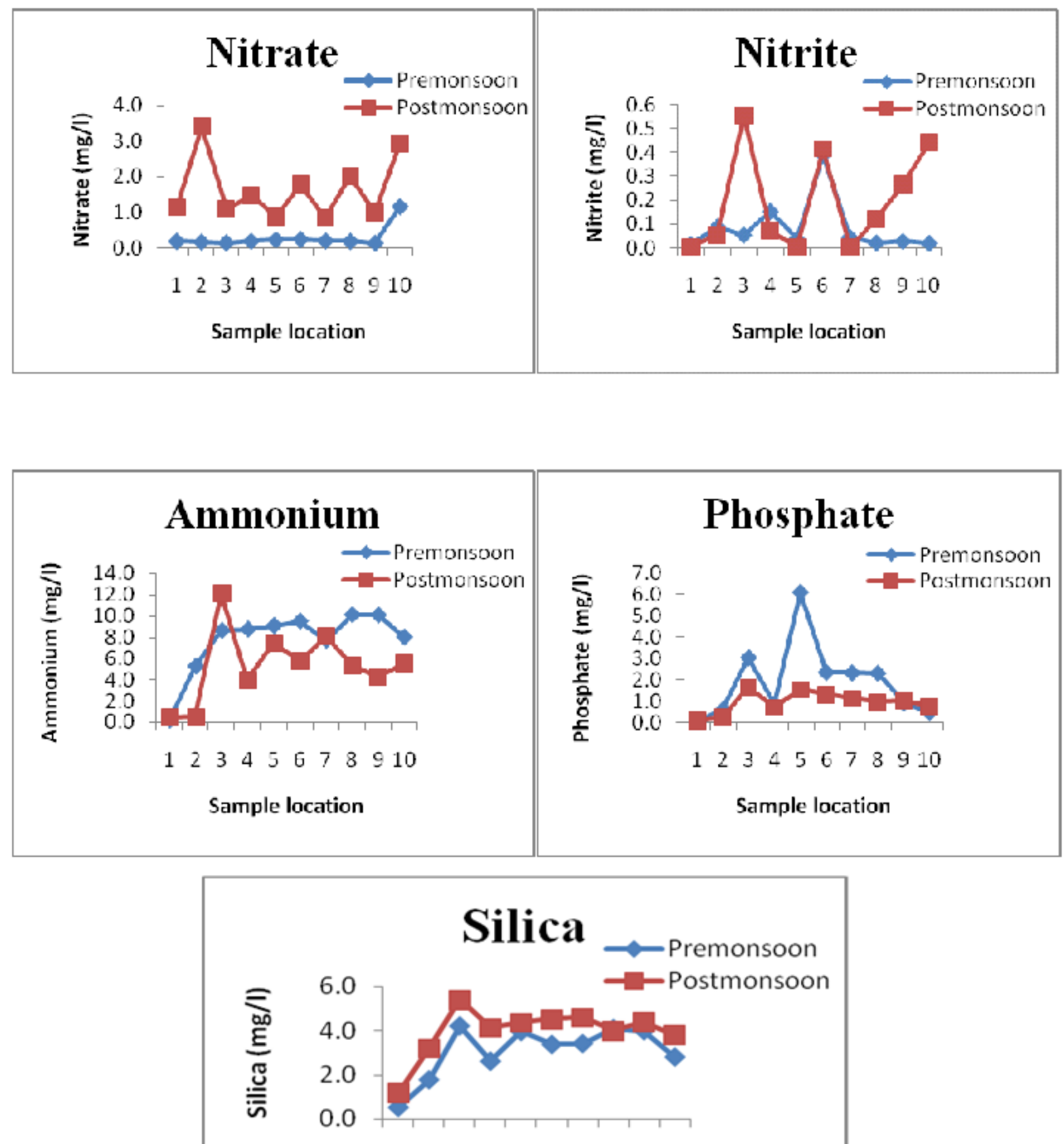

$\begin{array}{lllllllllll}1 & 2 & 3 & 4 & 5 & 6 & 7 & 8 & 9 & 10\end{array}$

Sample location 
Fig. 2b Seasonal variation of physiochemical parameters at different locations in Delhi region Yamuna water: $\mathrm{pH}$, Total dissolved solids (mg/l), Electrical conductivity $(\mu \mathrm{s} / \mathrm{cm})$, Dissolved oxygen $(\mathrm{mg} / \mathrm{l})$ and Biochemical oxygen demand $(\mathrm{mg} / \mathrm{l})$
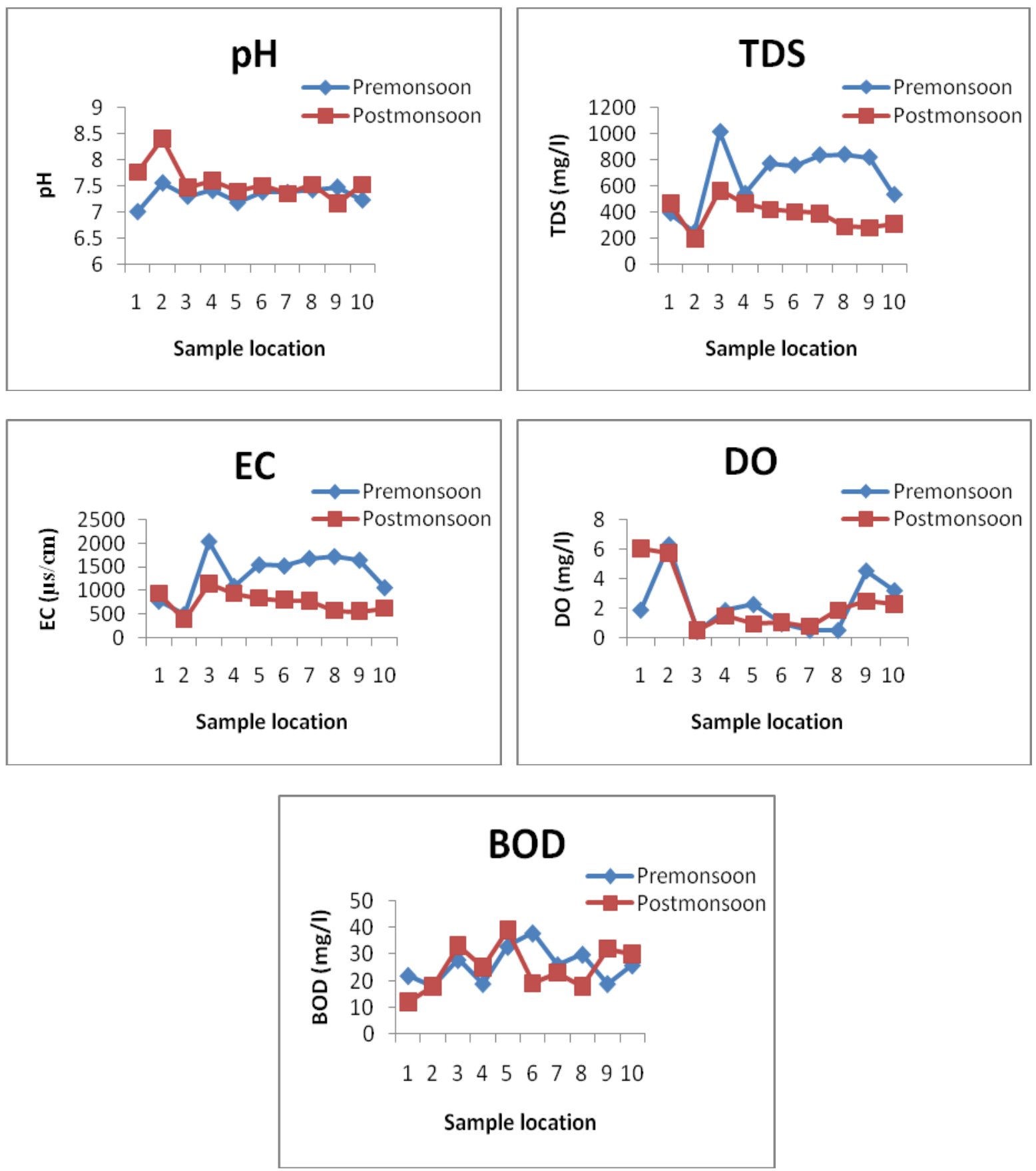
Fig.3 WQI for Yamuna river water in Delhi region

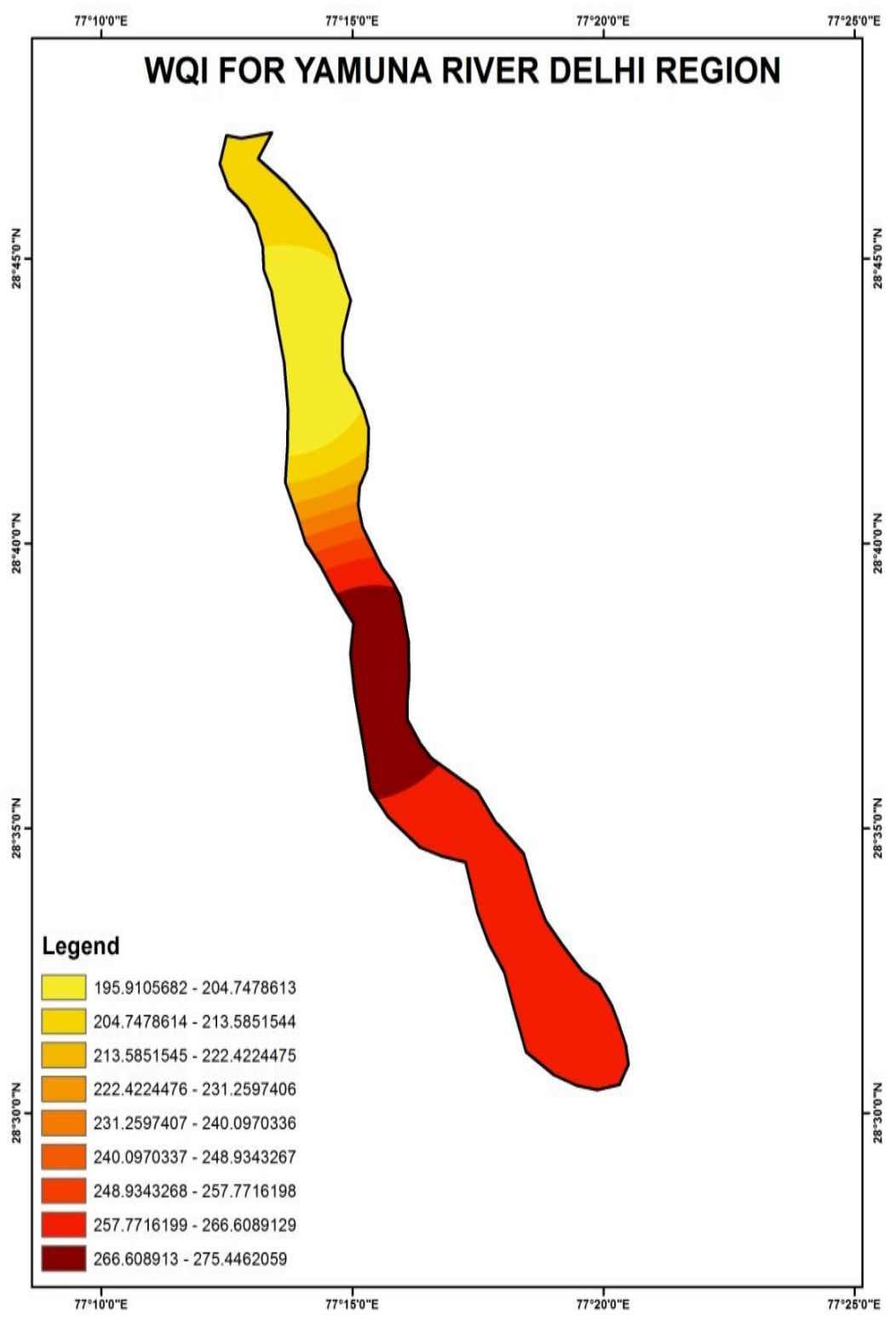

In the Yamuna River system spatial variation in nutrient concentration depends upon the land use pattern and population density. Anthropogenic inputs which show distinct but variable concentration peaks, mixes with urban and agricultural runoff are primarily responsible for increasing nutrient concentration in the fresh water of the river (Chambers et al., 2006) although temporal variability can be largely affected by variability in water discharge. Change in the
Nutrient concentration resulted to change in nutrient elemental ratios, Dissolve oxygen and $\mathrm{pH}$ value of river water, as increased nutrient loading causes severe local, regional and global eutophication problems (Billen and Garnier, 2007; Howarth, 2008) which leads to anoxic condition by depleting oxygen from river water. The concentration of DO was found minimum in Delhi stretches due to high organic loading from domestic sewage waste input which leads to depletion 
of oxygen from water body and death of aquatic organisms which indicated the problem of eutrophication in the entire stretch.

In conclusion, the WQI value integrated with GIS can be directly used to analyze and compare conditions in different Stretches of River and to detect its quality by trends. It will be useful for indicating the impairment of water quality with the water quality management practices. The present study revealed that the river water quality in Delhi is highly polluted due to addition from sewage waste and input from agricultural areas.

From the WQI and the obtained results for physicochemical parameters, it can be concluded that the Yamuna river water in Delhi is eutrophicated due to presence of low dissolved oxygen, high bio-chemical oxygen demand and high nitrate concentrations. It is unsuitable for the human uses. Hence, the water quality index technique along with nutrient elemental ratio is a useful tool for the overall assessment of water quality of a water body.

\section{Acknowledgement}

P.K. Jha is thankful to the Department of Science and Technology (DST), India for providing DST Young Scientist Project. The authors also thank Mr. Ali for providing assistance during sampling work and the Editor and anonymous reviewers for giving suggestions which have markedly improved the manuscript.

\section{References}

Charkhabi, A.H., M. Sakizadeh. 2003 Assessment of spatial variation of water quality parameter in the most polluted brabch of the Anzali
Wetland, Northern Iran, Polish J. Environ. Studies, 15: pp. 395-403

Abdel- Satar A.M., Goher M.E. and Sayed M.F. 2010. Recent Environmental changes in water and sediment quality of lake Quarum, Egypt. J. Fisheries and Aquatic Sci., 5(2), pp 56-69.

APHA. 1998. Standard methods for the examination of water and waste water analysis $\left(20^{\text {th }}\right.$ edn. $)$. American Public Health Association, AWWA.

Ambasht, R.S. 1971. Ecosystem study of a tropical pond in relation to primary production of different vegetation zones. Hydrobiologia , 12 : 57-61.

Atulegwu, P.U. and J.D. Njoku, 2004. The impact of biocides on the water quality. Int. Res. J. Eng. Sci. Technol., 1: 47-52.

Bahera, H., Pal, L. and Rout, S.P. 2004. Seasonal variations in the water quality index for Vani Vihar leke in Bhuvaneshwar. In: Water pollution (Ed: Aravind Kumar). A.P.H. Publ. Corp, New Delhi. Pp. 199-209.

BCMOELP. 1995. The British Columbia Water Quality Index, Water Quality Branch, Environmental Protection Department, British Columbia Ministry of Environment, Lands Parks, Victoria, B.C.

BIS. 1983. Standards for Water for Drinking and other purposes, Bureau of Indian Standards, New Delhi.

Billen, G., and J. Garnier. 2007. River basin nutrient delivery to the coastal sea: Assessing its potential to sustain new production of non-siliceous algae, Mar. Chem., 106, 148-160, doi: 110.1016.j. marchem.2006.1012.1017.

Brown, R.M., McLelland, N.I., Deininger, R.A. and Tozer, R.G. 1970. 'A water quality index -do we dare?', Water and Sewage Works, pp.339-343.

Canadian Council of Minister of the 
Environment $\quad$ (CCME). 2001 'Canadian water quality guidelines for the protection of aquatic life: CCME Water Quality Index 1.0', Technical report, Winnipeg MB, Canada.

Chambers, P.A., Culp, J., Glozier, N.E., Cash, K.J., Wrona, F.J., Noton, L. 2006. Northern rivers ecosystems initiative: nutrient and dissolved oxygen-issues and impacts. Environ. Monit. Assess, 113: 117-141

Chatterjee, A.A. 1992. Water quality of Nandakanan lake. India. J. Environ. Hlth., 34(4): 329-333.

Chaterjee, C. and Raziuddin, M. 2002. Determination of water quality index (WQI) of a degraded river in Asanol Industrial area, Raniganj, Burdwan, West Bengal. Nature, Environ. Pollution Technol., 1(2):181-189.

Chauhan, A. and Singh, S. 2010. Evaluation Of Ganga Water For Drinking Purpose By Water Quality Index At Rishikesh, Uttarakhand, India, Report and Opinion, 2(9): 53-61.

Chauhan, A., Goyal, P., Verma, A. and Jindal, T. 2015. Microbiological evaluation of drinking water sold by roadside vendors of Delhi, India. Appl. Water Sci., doi: 10.1007/s13201-015-0315-x.

Cloern, J.E. 2001. Our evolving conceptual model of the coastal eutrophication problem. Mar. Ecol. Progr. Ser., 210: 223-353.

Conley D.J., Schelske C.L. and Stoermer E.F. 1993. Modification of the biogeochemical cycle of silica with eutrophication. Mar. Ecol. Progr. Ser., 101: 179-192.

CPCB. 2006. Water quality status of Yamuna river.

Cude, C. 2001. 'Oregon Water Quality Index: a tool for evaluating water quality management effectiveness', $J$. American Water Res. Assoc., Vol. 37,
No. 1, pp.125-137, Oregon Department of Environmental Quality Laboratoy.

Elmanama, A.A., Afifi, S., and Bahr, S. 2006. Seasonal and spatial variation in the monitoring parameters of Gaza Beach during 2002-2003. Environ. Res., 101(1), 25-33

Goel, V., Kumar, A. and Verma, N.K. 2008. 'Quantitative study on microbial pollution of River Yamuna at Delhi', Indian J. Environ. Management, Vol. 5, No. 3, pp.113-124.

Gundogdu, K.S. and Guney, I. 2007. Spatial analyses of groundwater levels using universal kriging. J. Earth Sys. Sci., 116(1): pp. 49-55.

Halpern, B.S., Walbridge, S., Selkoe, K. A., Kappel, C. V., Micheli, F., D’Agrosa, C., Bruno, J. F., Casey, K. S., Ebert, C., Fox, H. E., Fujita, R., Heinemann, D., Lenihan, H. S., Madin, E. M. P., Perry, M. T., Selig, E. R., Spalding, M., Steneck, R., and Watson, R.: A global map of human impacts on marine ecosystems, Sci., 319, 948952.

Hopkinson, C.S. and Vallino, J.J. 1995.The nature of watershed perturbations and their influence on estuarine metabolism. Estuaries. 18, 598-621.

Horton, R. 1965. 'An index number system for rating water quality', WPCF, Vol. 37, No. 3, pp.300-306.

Howarth, R.W., et al. 1996. Regional nitrogen budgets and riverine $\mathrm{N}$ and $\mathrm{P}$ fluxes of the drainages to the North Atlantic Ocean: Natural and human influences, Biogeochemistry, 35, 2235-2240.

Isaaks, E. H. and R. M. Srivastava. 1989. An Introduction to Applied Geostatistics. Oxford Univ. Press, New York. Introductory textbook.

Justic' D., Rabalais N.N., Turner R.E. and Dortch Q. 1995. Changes in nutrient 
structure of river-dominated coastal waters: stoichiometric nutrient balance and its consequences. Estuar. Coast. Shelf Sci., 40: 339-356.

Kambalagere. Y., et al. 2007. Determination of water quality index and suitability of an urban waterbody in Shimoga Town, Karnataka, Proceedings of Taal, The $12^{\text {th }}$ World Lake Conference: $342-346$

Kaur, S. and Singh, I. 2012. Accelerated phosphate and nitrate level: Factors to blame for Eutrophication in Yamuna River, Delhi, India, Int. J. Plant, Animal and Environ. Sci., Volume2(3), pp. 183-187.

Kumar, A., Sharma, R.C. and Rathore, B. 2015. Determination of WQI of River Yamuna Between Mathura and Agra Region, Ultra Chem., Vol. 11(1), 7-14

Mandal Papaya, Rahul upadhyay and Aziz Hasan. Seasonal and spatial variation of Yamuna River water quality in Delhi, India. Environ. Monit. Assess, 170, 661- 670.

Meybeck, M. 1979. Concentrations des eaux fluviales en el'ements ma- 'jeurs et apports en solution aux oceans. Revue de Geologie Dynamique et de Geographie Physique, 21(3), 215246.

Misra, A.K. 2010. A River about to die: Yamuna, J. Water Res. Protection, 2, 489-500.

Morse, G.K., Lester, J.N., Perry, R. 1993. The economic and environmental impact of phosphorus removal from wastewater in the European community. Selper publication, London.

Murdoch, T., Cheo, M. and O'Laughlin, K. 2001. Streamkeeper's Field Guide: Watershed Inventory and Stream Monitoring Methods. Adopt-AStream Foundation, Everett, WA. 297 pp.
Officer, C.B. and Ryther, J.H. 1980. The possible importance of silicon in marine eutrophication. Mar. Ecol. Progr. Ser., 3: 383-391.

Paliwal, R., Sharma, P., Kansal, A. 2007. Water quality modelling of the river Yamuna (India) using QUAL2EUNCAS. J. Environ. Manag., 83(2): 131-144.

Qu, H.J. and Kroeze, C. 2010. Past and future trends in nutrients export by rivers to the coastal waters of China, Sci. Total Environ., 408: 2075-2086.

Rani, M., Akolkar, P. and Bhamrah, H.S. 2013. Water quality assessment of River Yamuna from origin to confluence to River Ganga, with respect to Biological water quality and primary water quality criteria, $J$. Entomol. Zool. studies, 1(6): 1-6.

Rawat, K.S., Mishra, A.K., Sehgal, V.K. and V.K. Tripathi. 2012. Spatial Variability of Ground Water Quality in Mathura District (Uttar Pradesh, India) with Geostatistical Method. Int. J. Remote sens. Appl., 2(1): 1-9.

Redfield, A.C., Ketchum, B.H., \& Richards, F.A. 1963. The influence of organisms on the composition of seawater. The sea (Vol. 2, pp. 26-77. New York: Wiley.

Schulze, D.L., Eggers, J.S., Esser, L.R. 2001. Water quality studies red rock and Saylorville Reservoirs DesMoines River, Lowa. Annual Report. Department of the Army, Rock Island District, Corps of Engineers, Rock Island, IL.

Seitzinger, S. P., Harrison, J. A., Dumont, E., Beusen, A. H. W., and Bouwman, A. F. 2005. Sources and delivery of carbon, nitrogen, and phosphorus to the coastal zone: an overview of global nutrient export from watersheds (NEWS) models and their application, Global Biogeochem. Cy., 
19,

GB4S01, doi:10.1029/2005GB002606, 2005

Shardendu, R.S. Ambasht, 1988. Limnological studies of a rural pond and an urban tropical aquatic ecosystem: oxygen enforms and ionic strength. J. Tropical Ecol., 29 (2): 98109.

Sharma, D., Singh, R.K. 2009. DO-BOD modeling of River Yamuna for national capital territory, India using STREAM II, a 2D water quality model. Environ. Monit. Assess., 159(1-4): 231-240.

Sharma, D., Gupta, R., Singh, R.K. and Kansal, A. 2012. Characteristics of the event mean concentration (EMCs) from rainfall runoff on mixed agricultural land use in the shoreline zone of the Yamuna River in Delhi, India, Appl. water sci., 2: 55-62.

Sinha, S.K. 1995. Potability of some rural ponds water at Muzaffarpur (Bihar)-A note on water quality index, J. Poll. Res., 14(1): 135-140.

State of Environment Report for Delhi. 2010. Department of Environment and Forests, Government of NCT of Delhi

\section{How to cite this article:}

Shikha Sharma, Pawan Kumar Jha, Manju Rawat Ranjan, Umesh Kumar Singh and Tanu Jinda. 2017. Water Quality Monitoring of Yamuna River by Using GIS Based Water Quality Index in Delhi, India. Int.J.Curr.Microbiol.App.Sci. 6(2): 1249-1263.

doi: http://dx.doi.org/10.20546/ijcmas.2017.602.141 